\title{
Antibacterial activity of Kombucha against Escherichia coli and Staphylococcus aureus and Minas Frescal cheese production with Scoby
}

\author{
Atividade antibacteriana do Kombuchá contra Escherichia coli e Staphylococcus aureus e Produção \\ de queijo Minas Frescal com Scoby \\ Actividad antibacteriana de Kombucha contra Escherichia coli y Staphylococcus aureus y \\ Producción de queso Minas Frescal con Scoby
}

Received: 01/13/2022 | Reviewed: 01/23/2022 | Accept: 01/27/2022 | Published: 01/28/2022

Eduardo Bergamaski Coelho

ORCID: https://orcid.org/0000-0003-2033-8132

State University of Maringá, Brazil

E-mail: brunabarneisaraiva@gmail.com

Bruna Barnei Saraiva

ORCID: https://orcid.org/0000-0002-6286-1864

State University of Maringá, Brazil

E-mail: brunabarneisaraiva@gmail.com

Bruna Moura Rodrigues

ORCID: https://orcid.org/0000-0001-6613-6689 State University of Maringá, Brazil

E-mail: bmrodrigues@live.com

Ranulfo Combuca da Silva Júnior

ORCID: https://orcid.org/0000-0001-6655-6368 State University of Maringá, Brazil E-mail: rcsjunior@uem.br

Katieli da Silva Souza Campanholi

ORCID: https://orcid.org/0000-0001-5156-8542 State University of Maringá, Brazil E-mail: katieli_souza@hotmail.com

Dayse Maria Bernardo Maricato ORCID: https://orcid.org/0000-0001-8660-2392 State University of Maringá, Brazil E-mail: daysemaricato@gmail.com

Paula Matumoto Pintro

ORCID: https://orcid.org/0000-0002-9182-5758 State University of Maringá, Brazil E-mail: ptmpintro@gmail.com

Magali Soares dos Santos Pozza ORCID: https://orcid.org/0000-0002-3500-1914 State University of Maringá, Brazil E-mail:msspozza@uem.br

\begin{abstract}
Functional ingredients have become common in food products. The fermented Kombucha drink stands out for its probiotic and antimicrobial properties that beneficially contribute to food use. The present study aimed at assessing the antimicrobial activity of Kombucha in experimentally contaminated cheeses. Therefore, Minas Frescal cheeses were prepared, inoculated with Escherichia coli and divided into three treatments: 1) lactic acid bacteria (BioRich $\left.{ }^{\circledR}\right)$; 2) lactic bacteria (BioRich $($ ) and $10 \mathrm{~g}$ of Scoby (symbiotic culture of bacteria and yeasts); 3 ) $10 \mathrm{~g}$ of Scoby. The gelatinous film (Scoby) was used to produce the Kombucha extract. The experimental design was a $3 \times 4$ factorial arrangement with three treatments and four evaluation times. Data was analyzed with ANOVA, and treatments means were compared with the Tukey test $(\mathrm{p} \leq 0.05)$. The parameters of minimum inhibitory concentration, color, texture, $\mathrm{pH}$, acidity, water activity, counting of yeasts, lactobacilli, and total coliforms were evaluated on days 0, 3, 6, and 9 of storage. Antibacterial action of Kombucha was compared against Escherichia coli and Staphylococcus aureus bacteria for minimum inhibitory concentration. Acidity, bacterial counting, yeasts, coliforms, lactobacilli, hardness, and gumminess showed significant changes with the addition of Kombucha to cheeses $(\mathrm{p} \leq 0.05)$. However, However, the
\end{abstract}


addition of Kombucha to the cheeses did not reduce the coliform content and negatively altered the texture parameters.

Keywords: Coliforms; Functional ingredient; Gelatinous film; Lactobacilli; Probiotic.

\begin{abstract}
Resumo
Ingredientes funcionais tornaram-se comuns em produtos alimentícios. A bebida fermentada de Kombuchá se destaca por suas propriedades probióticas e antimicrobianas que contribuem de forma benéfica quando utilizada na alimentação. O presente estudo teve como objetivo avaliar a atividade antimicrobiana do Kombuchá em queijos contaminados experimentalmente. Para tanto, foram preparados queijos Minas Frescal, inoculados com Escherichia coli e divididos em três tratamentos: 1) bactéria láctica (BioRich $\left.{ }^{\circledR}\right)$; 2) bactéria láctica (BioRich®) e 10 g de Scoby (cultura simbiótica de bactérias e leveduras); 3) $10 \mathrm{~g}$ de Scoby. O filme gelatinoso (Scoby) foi usado para produzir o extrato de Kombuchá. O delineamento experimental foi em esquema fatorial 3 x 4 com três tratamentos e quatro tempos de avaliação. Os dados foram analisados por meio de ANOVA e as médias dos tratamentos comparadas com o teste de Tukey $(\mathrm{p} \leq 0,05)$. Os parâmetros de concentração inibitória mínima, cor, textura, pH, acidez, atividade de água, contagem de leveduras, lactobacilos e coliformes totais foram avaliados nos dias 0, 3, 6 e 9 de armazenamento. A ação antibacteriana do Kombuchá foi comparada com as bactérias Escherichia coli e Staphylococcus aureus para concentração inibitória mínima. Acidez, contagem de bactérias, leveduras, coliformes, lactobacilos, dureza e gomosidade foram significativos na adição de Kombuchá aos queijos ( $\mathrm{x} \leq 0,05)$. A adição de kombuchá aos queijos não foi eficaz para promover menor crescimento de coliformes e alterou adversamente os parâmetros de textura.
\end{abstract}

Palavras-chave: Coliformes; Filme gelatinoso; Ingrediente funcional; Lactobacilos; Probiótico.

\title{
Resumen
}

Los ingredientes funcionales se han vuelto comunes en los productos alimenticios. La bebida fermentada Kombucha destaca por sus propiedades probióticas y antimicrobianas que brindan beneficios cuando se usa en alimentos. El presente estudio tuvo como objetivo evaluar la actividad antimicrobiana de Kombucha en quesos contaminados experimentalmente. Para ello, se prepararon quesos Minas Frescal, se inocularon con Escherichia coli y se dividieron en tres tratamientos: 1) bacterias lácticas (BioRich®); 2) bacterias del ácido láctico (BioRich®) y $10 \mathrm{~g}$ de Scoby (cultivo simbiótico de bacterias y levaduras); 3) $10 \mathrm{~g}$ de Scoby. Se utilizó una película de gelatina (Scoby) para producir el extracto de Kombucha. El diseño experimental fue en un esquema factorial 3 x 4 con tres tratamientos y cuatro tiempos de evaluación. Los datos se analizaron mediante ANOVA y las medias de tratamiento se compararon con la prueba de Tukey ( $\mathrm{p} \square$ 0.05). Los parámetros de concentración mínima inhibitoria, color, textura, pH, acidez, actividad de agua, recuento de levaduras, lactobacilos y coliformes totales se evaluaron los días 0, 3, 6 y 9 de almacenamiento. La acción antibacteriana de Kombucha se comparó con la de Escherichia coli y Staphylococcus aureus para una concentración inhibitoria mínima. Acidez, recuento bacteriano, levadura, coliformes, lactobacilos, dureza y pegajosidad fueron significativos en la adición de Kombucha a los quesos (p $\square$ 0.05). La adición de kombucha a los quesos no fue eficaz para promover un menor crecimiento de coliformes y alteró adversamente los parámetros de textura.

Palabras clave: Coliformes; Película gelatinosa; Ingrediente funcional; Lactobacilos; Probiótico.

\section{Introduction}

There is a growing demand for functional foods and the evolution of new market segments, which include functional drinks. Kombucha, a drink that originated in Asia, is a prominent sweet fermented product made from the infusion of Camellia sinensis leaves (green tea, black tea, or both) with sucrose (De Filippis et al., 2018; Coelho et al., 2020). Moreover, it has antioxidant activity, probiotic effect, anticarcinogenic action, hypoglycemic effect, antimicrobial, and antifungal potential (Medeiros and Cechinel-Zanchetti, 2019; Morales, 2020).

In order to prepare the drink, Scoby (symbiotic culture of bacteria and yeast) is used as an inoculum, which consists of a symbiotic colony composed of bacteria and yeasts responsible for Kombucha fermentation (Gramza-Michałowska et al., 2016). Besides, ethanol and acetic acid, produced during fermentation, have antimicrobial activity against pathogenic bacteria. This fact indicates that Kombucha can inhibit the growth of contaminating microorganisms.

Minas Frescal cheese stands out among the dairy derivatives. It is a raw dough product that has a high moisture content (46 to 55\%) and $\mathrm{pH}$ greater than 5.0, obtained by enzymatic coagulation of milk with coagulating enzymes, either complemented or not by fermenting bacteria (lactic acid bacteria) (Brasil, 1997; Magenis et al., 2014). These characteristics 
Research, Society and Development, v. 11, n. 2, e37711225721, 2022

(CC BY 4.0) | ISSN 2525-3409 | DOI: http://dx.doi.org/10.33448/rsd-v11i2.25721

make the Minas Frescal cheese a conducive mean to microbiological contamination due to the poor quality of the raw material, in addition to problems during the pasteurization process, hygiene deficiency of the instruments used in the preparation of cheese and handling of the curd, as well as inefficiency during product storage (Carvalho et al., 2007). Such production conditions are found in several countries.

Dyes, antioxidants, and natural antimicrobials, in addition to beneficial bacteria competing with deteriorating pathogenic microorganisms, appear as an alternative to maintain the product quality to prevent microbiological deterioration and increase the food shelf life (Campagnollo et al., 2018).

Vohra et al., (2019), studied the antimicrobial activity of Kombucha prepared from black tea and different sources of carbon (white sugar, brown sugar, and honey) against Escherichia coli, Staphylococcus aureus, Pseudomonas aeruginosa, Bacillus subtilis, and Serratia marcescens. They found an efficient antimicrobial action due to the combination of black tea and all sources of sugar.

Therefore, based on the association of Kombucha functional aspect with the high nutritional value of Minas frescal cheese, and also considering the demand of the consumer market for natural foods that benefit health, the present study aimed at assessing the microbiological and physical parameters of fresh cheeses with symbiotic culture from Kombucha or commercial lactic acid bacteria, besides to showing their action in E. coli control.

\section{Methodology}

The experiment was carried out at the Mesoregional Center of Excellence in Milk Technology (CMETL) from Iguatemi Experimental Farm (FEI) that belongs to the State University of Maringá (UEM), Brazil.

Bacterial suspensions of E. coli (E. coli) and S. aureus (S. aureus) strains (New Prove $\left.{ }^{\circledR}\right)$ were obtained through the culture in Brain Heart Infusion (BHI) broth (Enterococci BHI broth, Himedia Laboratories, Mumbai, India) at $30{ }^{\circ} \mathrm{C}$ for $24 \mathrm{~h}$. The preculture was subjected to serial decimal dilution in peptoned water to achieve a turbidity equivalent to 0.5 McFarland solution, determined by absorbance reading $(\lambda=630 \mathrm{~nm}$ ) in a spectrophotometer (Hach, DR 3900) between 0.080 and 0.100. Under this optical density range, the cell suspension contains approximately $1.0 \times 10^{8}$ colony-forming units (CFU) $\mathrm{mL}^{-1}$.

The activation of the Kombucha starter culture was carried out according to the manufacturer's recommendations. Thus, $4 \mathrm{~L}$ of distilled water, $100 \mathrm{~g}$ of refined sugar (União®) and 4 sachets of green tea (Leão@) were used. This mixture was deposited in a glass bottle with a volume of $5 \mathrm{~L}$ and autoclaved $15 \mathrm{~min}$ at $120{ }^{\circ} \mathrm{C}$. Next, the starter culture was added to the solution cooled, which followed the fermentation process at $25{ }^{\circ} \mathrm{C}$, resulting in a cellulose film on the liquid surface. This gelatinous film (Scoby) was used to produce the Kombucha extract; $10 \mathrm{~g}$ of the bio-gel was removed and crushed in a sterilized pistil to reach the ideal texture for dilution in sterile distilled water.

Analyzes in vitro of minimum inhibitory concentration (MIC) and minimum bactericidal concentration (MBC) of the Kombucha extract were performed and obtained by diluting it in sterile distilled water with 10\% dimethyl sulfoxide (DMSO) (Wayne, 2002). First, MIC was determined with the microdilution technique in Mueller Hinton broth (MH Broth) KASVIß in 96-well plates; $100 \mu \mathrm{L}$ of MH Broth was distributed in each well, $100 \mu \mathrm{L}$ of the Kombucha extract was added, followed by serial dilution, homogenization, and transfer of $100 \mu \mathrm{L}$ to the next well until the last well. After that, $5 \mu \mathrm{L}$ of the standardized microbial inoculum was added to each well of the plate; one column for the positive control (without extract and antibiotic Pentabiotico 6.000.000 IU Zoetis ${ }^{\circledR}$ ) another column for negative control (without extract and inoculum) were used. The plates were incubated at $37^{\circ} \mathrm{C}$ for $24 \mathrm{~h}$. Then, the Minimum Bactericidal Concentration (MBC) was determined using the subculture technique in Mueller Hinton KASVI ${ }^{8}$ Agar; $10 \mu \mathrm{L}$ of each well was transferred to the Agar and incubated at $37^{\circ} \mathrm{C}$ for $24 \mathrm{~h}$ according to CLSI recommendations (Clinical and Laboratory Standards Institute, 2009). 
Research, Society and Development, v. 11, n. 2, e37711225721, 2022

(CC BY 4.0) | ISSN 2525-3409 | DOI: http://dx.doi.org/10.33448/rsd-v11i2.25721

The counting of total mesophilic bacteria, both from fermented tea and Scoby, was performed by homogenizing 10 $\mathrm{mL}$ and $10 \mathrm{~g}$, respectively, in $90 \mathrm{~mL}$ of sterile peptoned water, followed by serial dilution and sowing in Dextrose Potato Agar KASVI ${ }^{\circ}(\mathrm{BDA})$ and Plate Count Agar KASVI ${ }^{\circ}(\mathrm{PCA})$. The plates were incubated at $35{ }^{\circ} \mathrm{C}(\mathrm{PCA})$ and $25^{\circ} \mathrm{C}(\mathrm{BDA})$ for $48 \mathrm{~h}$ (APHA, 2001).

The cheeses were produced with $30 \mathrm{~L}$ per repetition of milk obtained at the Dairy Cattle Sector from FEI. The milk was pasteurized at $65^{\circ} \mathrm{C}$ for $30 \mathrm{~min}$, cooled to $35^{\circ} \mathrm{C}$, and $2 \mathrm{~mL}$ of standardized E. coli was inoculated in $1.0 \times 10^{8} \mathrm{UFC} \mathrm{mL}^{-1}$ for every $10 \mathrm{~L}$ of milk. The milk was divided into three treatments: T1) BioRich ${ }^{\circledR}$ with Lactobacillus acidophilus LA-05, Bifidobacterium BB-12 and Streptococcus thermophilus (CHR Hansen, Denmark), one envelope for every 1 L of milk; T2) BioRich ${ }^{\circledR}$ and $10 \mathrm{~g}$ of Scoby; T3) $10 \mathrm{~g}$ of Scoby (bio-gel).

After adding the inoculum (BioRich ${ }^{\circledR}$ or Scoby), the milk was homogenized, and Estrella ${ }^{\circledR}$ rennet was added to all treatments (Laticínios Estrela, Estrela D’Oeste - SP, Brazil). After coagulation, the dough was cut, drained, and molded in polyethylene pans with a volume of $180 \mathrm{~mL}$, placed in sanitized trays. The cheeses were stored at 9 days in incubation (Cielab, CE 300-350) at $12{ }^{\circ} \mathrm{C}$. Physical (Aw, pH, acidity, texture, and color) and microbiological analyzes were performed in triplicate on days $1,3,6$, and 9 days of storage.

For microbiological analysis, $10 \mathrm{~g}$ of each cheese were homogenized in $90 \mathrm{~mL}$ of sterile peptone water, followed by serial decimal dilutions and seeding in the Dextrose Potato Agar KASVI® (BDA) media from Man Rogosa and Sharpe Hi Media Laboratories, Mumbai (MRS), India, and MacConkey (Hi Media Laboratories, Mumbai, India) for yeasts, lactobacilli and total coliforms, respectively (APHA, 2001).

For physical analyzes, water activity (Aw) was evaluated using digital equipment (Aqualab® 4TE, Decagon, São Paulo, Brazil); pH in digital bench pH meter (Tecnal Tec-5, Piracicaba, SP, Brazil), and the titratable acidity, expressed in ${ }^{\circ}$ Dornic, was determined by titration in $0.1 \mathrm{~N} \mathrm{NaOH}$ alkaline solution and phenolphthalein indicator to the equivalence point. For texture, a Texture Pro CT texturometer (Brook field Engineering Laboratories, Inc, Middleborough, MA, USA) was used; the equipment was calibrated with a standard weight of $5 \mathrm{~kg}$, with a descending and cutting speed of the device of $200 \mathrm{~mm}$ $\min ^{-1}$. The conditions used: TPA option; pre-test speed $5.0 \mathrm{~mm} \mathrm{~s}^{-1}$; test speed $1.0 \mathrm{~mm} \mathrm{~s}^{-1}$; post-test speed $5.0 \mathrm{~mm} \mathrm{~s}^{-1}$; compression distance $9.0 \mathrm{~mm}$. The color was determined by using the CIELAB system with Minolta ${ }^{\circledR}$ equipment for color parameters $\mathrm{L}^{*}$ (brightness from 0 to 100 ), $\mathrm{a}^{*}$ and $\mathrm{b}^{*}$ (chromaticity coordinates), where $\mathrm{a}^{*}$ variable is from green to red, and $\mathrm{b}^{*}$ variable from blue to yellow.

The experimental design was a $3 \times 4$ factorial with three treatments and four evaluation times (three replications per treatment, one cheese per experimental unit, weighing $90 \mathrm{~g}$ on average). Data were assessed with ANOVA using SAEG software (2007), and treatment means were compared with the Tukey test $(\mathrm{p} \leq 0.05)$.

\section{Results and Discussion}

According to Watawana, Jayawardena, Gunawardhana, Waisundara (2015), Kombucha may inhibit the growth of several pathogens: Helicobacter pylori, E. coli, Entamoeba cloacae, P. aeruginosa, S. aureus, Staphylococcus epidermis, Agrobacterium tumefaciens, Bacillus cereus, Salmonella typhi, Leuconostoc monocytogenes, Yersinia enterocolitica, Campylobacter jejuni, and Candida albicans. This activity is attributed to the low $\mathrm{pH}$ of the drink caused by acetic acid and catechins produced by bacteria and yeasts during the fermentation process, which inhibit the growth of several Gram-positive and Gram-negative microorganisms. 
Table 1. Average inhibitory concentration of Kombucha extract $\left(\mathrm{mg} \mathrm{mL}^{-1}\right)$ for Escherichia coli and Staphylococcus aureus.

\begin{tabular}{ccc}
\hline & Kombucha extract $\left(\mathrm{mg} \mathrm{mL}^{-1}\right)$ & $\log _{10} \mathrm{CFU} \mathrm{g}^{-1}$ \\
\hline & 200.00 & 3.62 \\
& 100.00 & 3.54 \\
& 50.00 & 3.15 \\
& 25.00 & 3.11 \\
& 12.50 & 3.30 \\
& 6.25 & 2.95 \\
Control & 3.13 & 3.28 \\
& 1.56 & 2.85 \\
\hline & 0,00 & 4,81 \\
\hline \multirow{2}{*}{ S. aureus } & 200.00 & 3.88 \\
& 100.00 & 3.67 \\
& 50.00 & 3.59 \\
& 25.00 & 3.59 \\
& 12.50 & 3.26 \\
& 6.25 & 3.20 \\
& 3.13 & 3.15 \\
& 1.56 & 3.40 \\
\hline
\end{tabular}

Control: Pentabiotico 6.000.000 UI. Source: Prepared by the authors.

The analysis of minimum inhibitory concentration evidenced antibacterial action against E. coli and S. aureus (Table 1). For E. coli strains, concentrations between 6.25 and $1.56 \mathrm{mg} \mathrm{mL}^{-1}$ of Kombucha extract obtained more significant results. For $S$. aureus higher values were found in the countings, but there was an inhibition of this bacterium by Kombucha extract.

The antimicrobial action of Kombucha corroborates the results obtained in the study by Cardoso, Busfield, Steiner \& de Oliveira Rosa (2018), in which Scobies were added to different types of sugar; then the fermented ones were inoculated into Petri dishes containing S. aureus ATCC 6538, Salmonella sp. ATCC 4598, E. coli ATCC 3328, Shigella ATCC 12022, and the fungus Candida albicans 10231. No growth of microorganisms was seen during the product storage. For the fermented product filtered through a nylon sieve and stored at $4{ }^{\circ} \mathrm{C}, \mathrm{C}$. albicans growth was seen in treatments fermented with black tea and sugar and fermented milk.

According to De Filippis et al. (2018), the variety and quantity of leaves used, concentration and choice of sugar, fermentation time, and composition of Scoby lead to differences in the composition and Kombucha antimicrobial activity.

Nguyen et al. (2015) reported that the addition of lactic acid bacteria in Kombucha could improve the production of acids, antimicrobial activity, and antioxidant capacity of the drink. Furthermore, among the bacterial isolates from the fermented tested (pickled cabbage and kefir), the bacteria isolated from kefir were better to improve the biological functions of Kombucha. Thus, it is assumed that the addition of Kombucha in dairy products, such as fresh cheese, potentiates the antibacterial action of microorganisms due to the association of lactic bacteria and yeasts.

The evaluation of the liquid and bio-gel (Scoby) product counting are in Table 2.

Table 2. Microorganism counts $\left(\log _{10} \mathrm{CFU} \mathrm{g}^{-1}\right)$ in Kombucha liquid and bio-gel.

\begin{tabular}{lcc}
\hline & Kombucha liquid & Kombucha gel \\
\hline Lactic acid bacteria & 1.66 & 2.79 \\
Fungi and yeast & 1.61 & 2.67 \\
\hline
\end{tabular}


The gelatinous film obtained higher microbiological countings when compared to the fermented liquid, as it is composed of Scoby, the symbiotic culture inoculum of bacteria and yeast responsible for the fermentation of Kombucha (Gramza-Michałowska, Kulczyński, Xindi \& Gumienna, 2016).

The acidity, $\mathrm{pH}$, and water activity (Aw) are in Table 2.

Table 3. Average values for acidity, $\mathrm{pH}$, and water activity (Aw)

\begin{tabular}{|c|c|c|c|c|c|c|c|c|c|}
\hline \multirow{2}{*}{ Time (d) } & \multicolumn{3}{|c|}{ Acidity } & \multicolumn{3}{|c|}{$\mathrm{pH}$} & \multicolumn{3}{|c|}{ Aw } \\
\hline & $\mathrm{T} 1$ & $\mathrm{~T} 2$ & T3 & $\mathrm{T} 1$ & $\mathrm{~T} 2$ & T3 & $\mathrm{T} 1$ & $\mathrm{~T} 2$ & T3 \\
\hline$\overline{0}$ & $0.50^{\mathrm{a}}$ & $0.70^{\mathrm{a}}$ & $0.57^{\mathrm{a}}$ & 6.70 & 6.19 & 5.65 & $0.83^{\mathrm{a}}$ & $0.85^{\mathrm{a}}$ & $0.84^{\mathrm{a}}$ \\
\hline 3 & $0.83^{\mathrm{ab}}$ & $0.93^{\mathrm{ab}}$ & $0.63^{\mathrm{b}}$ & 6.22 & 6.26 & 6.27 & $0.84^{\mathrm{a}}$ & $0.85^{\mathrm{a}}$ & $0.84^{\mathrm{a}}$ \\
\hline 6 & $1.60^{\mathrm{a}}$ & $1.27^{\mathrm{b}}$ & $0.87^{\mathrm{c}}$ & 6.17 & 6.31 & 6.49 & $0.84^{\mathrm{b}}$ & $0.89^{\mathrm{a}}$ & $0.81^{\mathrm{b}}$ \\
\hline 9 & $1.33^{\mathrm{b}}$ & $1.50^{\mathrm{ab}}$ & $1.73^{\mathrm{ab}}$ & 5.94 & 6.05 & 6.21 & $0.85^{\mathrm{a}}$ & $0.82^{\mathrm{a}}$ & $0.83^{\mathrm{a}}$ \\
\hline $\mathrm{P}$ treatment & & 0.058 & & & NS & & & 0.085 & \\
\hline P time & & 0.000 & & & NS & & & NS & \\
\hline $\mathrm{P}$ interaction & & 0.000 & & & 0.247 & & & 0.034 & \\
\hline
\end{tabular}

T1: BioRich ${ }^{\circledR} ; \mathrm{T} 2:$ BioRich ${ }^{\circledR}$ and Scoby; T3: Scoby; * Means with different letter in a row are statistically different (Tukey, $\left.\mathrm{p} \leq 0.05\right)$. Acidity $\mathrm{T} 1 \mathrm{Y}=0.250+0.326667 \mathrm{x} ; \mathrm{T} 2 \mathrm{Y}=0.416667+0.27 \mathrm{x} ; \mathrm{T} 3 \mathrm{Y}=0.016667+0.37333 \mathrm{x}$. Source: Prepared by the authors.

Regarding the acidity parameter during storage (days 3 and 6), lower means for the treatment containing only Kombucha extract were found when compared to treatments with BioRich ${ }^{\circledR}$ and combination of BioRich ${ }^{\circledR}$ with Kombucha (Table 3). Oliveira et al. (2018) used cheeses without lactic acid bacteria, and obtained acid values of 0.78 for 3 days of maturation and 0.65 for $10 \mathrm{~d}$.

For fresh cheeses, Ordinance No. 352/1997 (Brasil, 1997) determines that they must comply with the provisions of the General Technical Regulation for Setting Microbiological Requirements for Cheeses (Ordinance No. 146/1996); besides, they must comply with the maximum limit for molds and yeasts of $5 \times 10^{3} \mathrm{UFC} \mathrm{g}^{-1}$. Counting of yeast/fungi, coliforms, and lactobacillus are in Table 4.

Table 4. Microorganisms counts $\left(\log _{10} \mathrm{CFU} \mathrm{g}^{-1}\right)$ in cheeses produced with Kombucha.

\begin{tabular}{|c|c|c|c|c|c|c|c|c|c|}
\hline \multirow{2}{*}{ Time (days) } & \multicolumn{3}{|c|}{ Yeast } & \multicolumn{3}{|c|}{ Coliform } & \multicolumn{3}{|c|}{ Lactobacilli } \\
\hline & $\mathrm{T} 1$ & $\mathrm{~T} 2$ & $\mathrm{~T} 3$ & $\mathrm{~T} 1$ & $\mathrm{~T} 2$ & $\mathrm{~T} 3$ & $\mathrm{~T} 1$ & $\mathrm{~T} 2$ & $\mathrm{~T} 3$ \\
\hline 0 & $<1.00^{c}$ & $2.92^{\mathrm{b}}$ & $3.17^{\mathrm{a}}$ & $1.97^{\mathrm{c}}$ & $2.38^{\mathrm{b}}$ & $2.97^{a}$ & $2.90^{\mathrm{b}}$ & $5.60^{\mathrm{a}}$ & $5.41^{\mathrm{a}}$ \\
\hline 3 & $<1.00^{\mathrm{c}}$ & $3.49^{\mathrm{b}}$ & $4.62^{\mathrm{a}}$ & $1.99^{\mathrm{c}}$ & $2.77^{\mathrm{b}}$ & $3.67^{\mathrm{a}}$ & $3.54^{\mathrm{b}}$ & $5.01^{\mathrm{a}}$ & $4.48^{\mathrm{a}}$ \\
\hline 6 & $<1.00^{\mathrm{c}}$ & $2.94^{\mathrm{b}}$ & $4.75^{\mathrm{a}}$ & $1.87^{\mathrm{b}}$ & $2.95^{\mathrm{a}}$ & $3.10^{\mathrm{a}}$ & $2.55^{\mathrm{c}}$ & $3.73^{\mathrm{b}}$ & $4.69^{\mathrm{a}}$ \\
\hline 9 & $<1.00^{\mathrm{b}}$ & $3.98^{\mathrm{a}}$ & $3.86^{\mathrm{a}}$ & $1.71^{\mathrm{b}}$ & $2.87^{\mathrm{a}}$ & $3.05^{\mathrm{a}}$ & $3.77^{\mathrm{b}}$ & $5.02^{\mathrm{a}}$ & $3.75^{\mathrm{b}}$ \\
\hline $\mathrm{P}$ treatment & & 0.00001 & & & 0.00001 & & & 0.00001 & \\
\hline P time & & 0.00001 & & & 0.00006 & & & 0.00003 & \\
\hline $\mathrm{P}$ interaction & & 0.00001 & & & 0.00004 & & & 0.00001 & \\
\hline
\end{tabular}

T1: BioRich ${ }^{\circledR} ;$ T2: BioRich ${ }^{\circledR}$ and Scoby; T3: Scoby; * Means with different letter in a row are statistically different (Tukey, $\left.\mathrm{p} \leq 0.05\right)$. Yeast $\mathrm{T} 2 \mathrm{Y}=2.678+0.261 \mathrm{x} ; \mathrm{T} 3 \mathrm{Y}=3.548+0.221 \mathrm{x}$. Coliforms: $1 \mathrm{Y}=2.113-0.0906 \mathrm{x}, \mathrm{T} 2 \mathrm{Y}=2.336+0.163319 \mathrm{x}, \mathrm{T} 3 \mathrm{Y}=3.280-0.034 \mathrm{x}$ Lactobacilli: $\mathrm{T} 1 \mathrm{Y}=2.789+0.160 \mathrm{x}, \mathrm{T} 2 \mathrm{Y}=5.595-0.302 \mathrm{x}, \mathrm{T} 3 \mathrm{Y}=5.767-0.4752 \mathrm{x}$. Source: Prepared by the authors.

Cheeses with the addition of Kombucha obtained higher counting means of yeast/fungi, coliforms, and lactobacillus (Table 4). Since yeasts are harmful to the cheese structure, according to Zacarchenco, Trento, Spadoti, Gallina \& Silva (2011), some intensely proteolytic yeasts produce odorous cheese. The smell is reminiscent of rotten eggs, and it is often associated 
with white dots on the surface of cheeses. Furthermore, the lipolytic activity of yeasts can lead to the formation of rancid flavors and aromas due to the presence of free fatty acids.

A maximum of $10^{2} \mathrm{CFU} \mathrm{g}^{-1}$ for the coliforms is established by Ordinance 352/1997 (Brazil, 1997). Lactic acid, acetic acid, ethanol, $\mathrm{CO}_{2}$, and $\mathrm{H}_{2}$ are the main compounds produced by the coliform group bacteria. Gas production starts to become apparent when the microorganism counting reaches approximately 100 to $400 \mathrm{CFU}$ of coliforms $\mathrm{g}^{-1}$ of cheese. These compounds are also responsible for the increasing acidity, which was more evident in the treatment acidity means containing commercial yeast and the addition of both.

An incidence of contamination by coliforms in fresh cheeses is common in Brazil. Oliveira et al. (2017) observed that $55.6 \%$ of the fresh cheese samples assessed in their study were not in accordance with the legislation for total coliforms, and $27.8 \%$ for coliforms at $45{ }^{\circ} \mathrm{C}$. Lima and Cardoso (2019) also showed total coliform and coliforms contamination at $45{ }^{\circ} \mathrm{C}$ in $100 \%$ of the fresh cheese samples sold at open markets. These data indicate unsatisfactory hygienic conditions during the production stages, which is risky for the consumers' health.

The addition of Kombucha was not efficient in reducing coliforms in cheeses (Table 4); the limit for high humidity cheeses consists of $5 \times 10^{3} \mathrm{UFC} \mathrm{g}^{-1}$ (Brasil, 2001). Lactic acid bacteria also showed higher countings in treatments containing Kombucha (Table 4). These microorganisms are extremely significant for the production of milk derivatives. In a study by Marsh et al. (2014), lactic bacteria Lactobacillus and Lactococcus were also detected in Kombucha; the lactobacilli were 99\% identical to Lactobacillus kefiranofaciens subsp. Kefir granum.

Texture (elasticity and cohesiveness) did not significantly differ among treatments, time, and treatments $\mathrm{x}$ time interaction. However, there was a difference between treatments for the hardness and gumminess parameters (Table 5).

Table 5. Hardness and gumminess parameters in cheeses produced with Kombucha.

\begin{tabular}{|c|c|c|c|c|c|c|}
\hline \multirow{2}{*}{ Time (days) } & \multicolumn{3}{|c|}{ Hardness (Kgf) } & \multicolumn{3}{|c|}{ Gumminess (g) } \\
\hline & $\mathrm{T} 1$ & $\mathrm{~T} 2$ & T3 & $\mathrm{T} 1$ & $\mathrm{~T} 2$ & T3 \\
\hline 0 & $0.960^{\mathrm{a}}$ & $0.331^{\mathrm{b}}$ & $0.228^{\mathrm{c}}$ & $932.00^{\mathrm{a}}$ & $249.67^{b}$ & $187.33^{\mathrm{b}}$ \\
\hline 3 & $1.148^{\mathrm{a}}$ & $0.685^{\mathrm{b}}$ & $0.511^{\mathrm{c}}$ & $1072.0^{\mathrm{a}}$ & $647.00^{\mathrm{b}}$ & $520.67^{b}$ \\
\hline 6 & $1.076^{\mathrm{a}}$ & $1.083^{\mathrm{a}}$ & $0.635^{\mathrm{b}}$ & $935.67^{\mathrm{a}}$ & $983.00^{\mathrm{a}}$ & $573.67^{b}$ \\
\hline $\mathrm{P}$ treatment & & 0.001 & & & 0.001 & \\
\hline P time & & 0.001 & & & 0.001 & \\
\hline $\mathrm{P}$ interaction & & 0.005 & & & 0.023 & \\
\hline
\end{tabular}

T1: BioRich ${ }^{\circledR} ; \mathrm{T} 2:$ BioRich ${ }^{\circledR}$ and Scoby; T3: Scoby; * Means with different letter in a row are statistically different (Tukey, $\left.\mathrm{p} \leq 0.05\right)$. Hardness: $\mathrm{T} 1 Y=945+58.333 x, T 2 Y=-51.667+375.833 x$, T3 $Y=51.667+203.333 x$. Gumminess: T1 $Y=976.222+1.833 x$, T2 $Y=-106.778+366.667 x, T 3 Y=40.889+193.167 x$. Source: Prepared by the authors.

The control treatment proved to be better than the other treatments, and a tendency to increase hardness during the product shelf life was seen. The gumminess parameter represents the energy required to make a piece of cheese ready to be swallowed. For this parameter, the treatments containing Kombucha obtained the lowest values and increased shelf life, a behavior similar to that of hardness.

According to Tomar (2019), water loss, oxidation and microbial proliferation are responsible for changing the color of cheeses, with the outer part being more affected, due to its direct contact with oxygen. 
Table 6. Luminosity parameters (L) in cheeses produced with Kombucha.

\begin{tabular}{|c|c|c|c|c|c|c|}
\hline \multirow{2}{*}{ Time (days) } & \multicolumn{3}{|c|}{ Outside } & \multicolumn{3}{|c|}{ Inside } \\
\hline & $\mathrm{T} 1$ & $\mathrm{~T} 2$ & T3 & T1 & $\mathrm{T} 2$ & T3 \\
\hline 0 & 88.51 & 88.29 & 87.89 & 88.53 & 88.34 & 88.32 \\
\hline 3 & 89.01 & 88.97 & 89.80 & 88.67 & 89.48 & 89,78 \\
\hline 6 & 86.42 & 83.46 & 87.19 & 88.18 & 89.21 & 89.38 \\
\hline P treatment & & 0.106 & & & NS & \\
\hline P time & & 0.001 & & & 1.178 & \\
\hline $\mathrm{P}$ interaction & & 0.124 & & & NS & \\
\hline
\end{tabular}

T1: BioRich®; T2: BioRich ${ }^{\circledR}$ and Scoby; T3: Scoby; * Means with different letter in a row are statistically different (Tukey, $\leq \leq 0.05$ ). Luminosity (L) outside of cheeses: T1 Y $=104.121+11.585 x$; T2 Y = 91.741 $-3522.417 x$; T3 Y $=89.004-0.353 x$. Source: Prepared by the authors.

Table 7. Colors parameters ( $\left.\mathrm{a}^{*}\right)$ in cheeses produced with Kombucha.

\begin{tabular}{lcccccc}
\hline \multirow{2}{*}{ Time (days) } & \multicolumn{3}{c}{ Outside } & \multicolumn{2}{c}{ Inside } \\
\cline { 2 - 6 } & $\mathrm{T} 1$ & $\mathrm{~T} 2$ & $\mathrm{~T} 3$ & $\mathrm{~T} 1$ & $\mathrm{~T} 2$ & 2.21 \\
\hline 0 & 2.07 & 2.21 & 2.23 & 2.08 & 1.94 & 2.22 \\
3 & 2.09 & 1.82 & 1.82 & 2.02 & 2.05 & 2.47 \\
\hline 6 & 3.57 & 1.46 & 2.13 & 2.06 & 0.184 & 0.035 \\
\hline P treatment & & 0.000 & & 0.323 \\
P time & & 0.006 & & & \\
P interaction & & 0.000 & & & \\
\hline
\end{tabular}

Outside of cheeses: T1 Y $=1.08667+0.746667 \mathrm{x}$; T2 $\mathrm{Y}=2.5822-0.37333 \mathrm{x}$; T3 $\mathrm{Y}=2.15889-4.8333 \mathrm{x}$. Inside of cheeses: $\mathrm{T} 1 \mathrm{Y}=2.07444$ $-0.008333 x ;$ T2 $Y=2.23333-0.081667 x ;$ T3 $Y=1.98+0.125 x$. Source: Prepared by the authors.

Table 8. Colors parameters $\left(b^{*}\right)$ in cheeses produced with Kombucha.

\begin{tabular}{lcccccc}
\hline \multirow{2}{*}{ Time (days) } & \multicolumn{3}{c}{ Outside } & \multicolumn{3}{c}{ Inside } \\
\cline { 2 - 7 } & $\mathrm{T} 1$ & $\mathrm{~T} 2$ & $\mathrm{~T} 3$ & $\mathrm{~T} 1$ & $\mathrm{~T} 2$ & 5.29 \\
\hline 0 & 5.75 & 5.4 & 5.45 & 5.59 & 5.07 & 5.46 \\
3 & 5.97 & 5.83 & 6.34 & 5.96 & 8.54 & 9.06 \\
6 & 13.22 & 14.01 & 10.93 & 8.81 & & 0.080 \\
P treatment & & 0.057 & & 0.000 & 0.140 \\
P time & & 0.000 & & & \\
P interaction & 0.028 & & & \\
\hline
\end{tabular}

Outside of cheeses: $\mathrm{T} 1 \mathrm{Y}=-1.685+5.633 \mathrm{x} ; \mathrm{T} 2 \mathrm{Y}=0.192+4.305 \mathrm{x} ; \mathrm{T} 3 \mathrm{Y}=2.095+2.74 \mathrm{x}$. Inside of cheeses $\mathrm{T} 1 \mathrm{Y}=3.567+1.61 \mathrm{x} ; \mathrm{T} 2 \mathrm{Y}=$ $3.22+1.622 x ; \mathrm{T} 3 \mathrm{Y}=3.22+1.621 \mathrm{x}$. Source: Prepared by the authors.

There was no significant difference between treatments for the luminosity parameter for treatment and time interaction. The $\mathrm{a}^{*}$ mean values observed outside were different $(p \leq 0.05)$ between treatments: $2.58,2.06$, and 1.83 , and a greater trend for the red color in cheeses with commercial bacteria (Table 6, 7, and 8).

\section{Conclusion}

Cheeses fermented with Kombucha showed higher microbiological countings for yeasts, fungi, lactobacilli, and coliforms. Therefore, its use was not efficient to control the coliforms. Kombucha in cheeses provided lower acidity 
values and lower index of hardness and gumminess; therefore, its addition to cheeses is not recommended. Future research should focus on developing high quality commercial products that are sensory acceptable to consumers with the inclusion of Kombucha.

\section{References}

American Public Health Association (APHA). (2001). Compendium of Methods for the Microbiological Examination of Foods, (4a ed.), American Public Health Association, 676p.

Brasil, Anvisa. Agência Nacional de Vigilância Sanitária. (2001). Resolução RDC N 12, de 02 de Janeiro de 2001. Regulamento técnico sobre padrões microbiológicos para alimentos. Diário Oficial da União, 10: 45-53.

Brasil. Ministério da Agricultura, Pecuária e Abastecimento. (1997). Ordinance $\mathrm{N}^{\circ}$ 352, de 04 de setembro de 1997. Aprova o Regulamento Técnico para Fixação de Identidade e Qualidade de Queijo Minas Frescal. Diário Oficial da União de 08/09/1997, Seção 1. pp: 19684.

Campagnollo, F. B. L. P., Margalho, B. A., Kamimura, M. D., Feliciano, L. Freire, L. S., \& Sant'Ana., A. S. (2018). Selection of indigenous lactic acid bacteria presenting anti-listerial activity, and their role in reducing the maturation period and assuring the safety of traditional Brazilian cheeses. Food Microbiology. 73: 288-297.

Cardoso, S. B. I. C., Busfield, E., Steiner, \& de Oliveira Rosa, T. R. (2018). Avaliação física, química e antimicrobiana da Kombucha Probiótico (Medusomyces gisevii lindau) e análise comparativa com outros probióticos comercializados no Brasil. Nutrição Brasil. 17: 2-8.

Carvalho, J. D. G., Viotto, W. H., \& Kuaye A. Y. (2007). The quality of Minas Frescal cheese produced by different technological processes. Food Control, 18: 262-267.

CLSI. Clinical and Laboratory Standards Institute. (2009). Performance Standards for Antimicrobial Disk Susceptibility Test; Approved Standand-Tenth Edition. Wayne, CLSI document M02-A10.

Coelho, R. M. D., Almeida, A., do Amaral, R. Q. G., da Mota, R. N., \& de Sousa, P. H. M. (2020). Kombucha. International Journal of Gastronomy and Food Science, 100272

De Filippis, F., Troise, A. D., Vitaglione P., \& Ercolini, D. (2018). Different temperatures select distinctive acetic acid bacteria species and promotes organic acids production during Kombucha tea fermentation. Food Microbiology, 73: 11-16.

Gramza-Michałowska, A., B., Kulczyński, Y., Xindi, \& Gumienna, M. (2016). Research on the effect of culture time on the kombucha tea beverage? antiradical capacity and sensory value. Acta Scientiarum Polonorum Technologia Alimentaria, 15: 447-457.

Junior, S. E. B., Miyaoka, M. F., da Luz Costa, J., Benavente, C. A. T., Couto, G. H., \& Soccol, C. R. (2012). Inibição do crescimento de bactérias Gramnegativas em microdiluição por tratamento com Nisina e EDTA. J. Journal of Biotechnology and Biodiversity, 3: 127-135.

Lima, A. A., \& Cardoso, A. J. V. S. (2019). Qualidade microbiológica de queijo Minas frescal, artesanal, comercializados em feiras livres do Distrito Federal/Microbiological quality of Minas Frescal Cheese, handcrafted, marketed at free fairs of the Federal District. Brazilian Journal of Development, 5(9): $13673-13688$

Magenis, R. B., Prudêncio, E. S., Fritzen-Freire, C. B., Stephan, M. P., do Egito, A. S., \& Daguer, H. (2014). Rheological, physicochemical and authenticity assessment of Minas Frescal cheese. Food Control, 45, 22-28.

Marsh, A. J., O'Sullivan, O., Hill, C., Ross, R. P., \& Cotter, P. D. (2014). Sequence-based analysis of the bacterial and fungal compositions of multiple kombucha (Tea fungus) samples. Food Microbiology, 38: 171-178.

Medeiros, S. C. G., \& Cechinel-Zanchett, C. C. (2019). Kombucha: efeitos in vitro e in vivo. Infarma-Ciências Farmacêuticas, 31(2): 73-79.

Morales, D. (2020). Biological activities of kombucha beverages: The need of clinical evidence. Trends in Food Science \& Technology.

Nguyen, N. K., Dong, N. T. N., \& Nguyen, H. T. (2015). Lactic acid bacteria: promising supplements for enhancing the biological activities of kombucha. Springerplus, 4(1): 91.

Oliveira, A. M., Kurihara, R. Y., da Silva, F. F., Godoi Silva, F., Júnior, de J. C. R., \& Beloti, V. (2017). Condições higiênico-sanitárias da produção de queijos tipo mussarela e minas frescal comercializados no norte do Paraná. Revista do Instituto de Laticínios Cândido Tostes, $72(1)$ : $40-47$.

Oliveira, S. P. P., Martins, J. M., Nogueira, C. H., do Vale, R. C., Rodrigues, M. P. J., \& Galleti, A. N. (2018). Características físico-químicas de queijo Minas artesanal do Serro fabricados com pingo e com rala. Revista do Instituto de Laticínios Cândido Tostes, 73(4): 235-244.

Tomar, O. (2019). The effects of probiotic cultures on the organic acid content, texture profile and sensory attributes of Tulum cheese. International Journal of Dairy Technology, 72(2), 218-228.

Vohra, B. M., Fazry, S., Sairi, F., \& Babul-Airianah,O. (2019). Effects of medium variation and fermentation time on the antioxidant and antimicrobial properties of Kombucha. Malaysian Journal of Fundamental and Applied Sciences, 15(2-1): 298-302.

Watawana, M. I., Jayawardena, N., Gunawardhana, C. B., \& Waisundara, V. Y. (2015). Health, wellness, and safety aspects of the consumption of kombucha. Journal of Chemistry, 1-11.

Wayne, P.A. (2002). NCCLS (National Committee for Clinical Laboratory Standards) Method for dilution antimicrobial susceptibility tests of bacteria that grow aerobically. Approved Standard. M100-S12.

Zacarchenco, P., Trento, F., L., Spadoti, D., Gallina, D., \& Silva, A. (2011). Bolores e leveduras em queijos. Revista Leite \& Derivados, ano XX, (129): 9299 